\title{
350 Years of Fire-Climate-Human Interactions in a Great Lakes Sandy Outwash Plain
}

\author{
Richard P. Guyette ${ }^{1, *}$, Michael C. Stambaugh ${ }^{1}$, Daniel C. Dey ${ }^{2}$, Joseph M. Marschall ${ }^{1}$, \\ Jay Saunders ${ }^{3}$ and John Lampereur ${ }^{3}$ \\ 1 Missouri Tree-Ring Laboratory, School of Natural Resources, University of Missouri, 203 ABNR Building, \\ Columbia, MO 65211, USA; stambaughm@missouri.edu (M.C.S.); marschallj@missouri.edu (J.M.M.) \\ 2 U.S. Forest Service, Northern Research Station, 11 Campus Blvd., Suite 200. Newtown Square, \\ PA 19073, USA; ddey@fs.fed.us \\ 3 U.S. Forest Service, Chequamegon-Nicolet National Forest, 500 Hanson Lake Road, Rhinelander, \\ WI 54501, USA; jsaunders@fs.fed.us (J.S.); jlampereur@fs.fed.us (J.L.) \\ * Correspondence: guyetter@missouri.edu; Tel.: +01-573-882-7741
}

Academic Editors: Sylvie Gauthier and Yves Bergeron Received: 30 June 2016; Accepted: 18 August 2016; Published: 27 August 2016

\begin{abstract}
Throughout much of eastern North America, quantitative records of historical fire regimes and interactions with humans are absent. Annual resolution fire scar histories provide data on fire frequency, extent, and severity, but also can be used to understand fire-climate-human interactions. This study used tree-ring dated fire scars from red pines (Pinus resinosa) at four sites in the Northern Sands Ecological Landscapes of Wisconsin to quantify the interactions among fire occurrence and seasonality, drought, and humans. New methods for assessing the influence of human ignitions on fire regimes were developed. A temporal and spatial index of wildland fire was significantly correlated $(r=0.48)$ with drought indices (Palmer Drought Severity Index, PDSI). Fire intervals varied through time with human activities that included early French Jesuit missions, European trade (fur), diseases, war, and land use. Comparisons of historical fire records suggest that annual climate in this region has a broad influence on the occurrence of fire years in the Great Lakes region.
\end{abstract}

Keywords: anthropogenic fire regimes; humans; red pine; ignition; drought

\section{Introduction}

In much of eastern North America, the quantitative data describing historical fire regimes over the last several centuries hinge on fire-scarred wood and trees. Annual resolution fire scar histories provide data and perspective on past fire intervals, fire extent, fire severity, and forcing factors that inform forest management and restoration [1]. For fire history, northern Wisconsin is a unique study region because of the considerable body of early written human history and the abundance of dateable and fire scarred wood. With these sources, excellent potential exists to study interactions among humans, climate, and fire.

Although droughts tend to occur infrequently in this cool-wet climate region, they have been associated with occurrences of high severity and culturally significant fire events (e.g., Peshtigo Fire of 1871). Attribute data from the 1800s General Land Office survey notes describe the historically complex vegetation patterning of northern Wisconsin ecosystems and the influence of drought and fire [2,3]. Multi-century fire scar records in the Great Lakes Region indicate that increased fire frequency, extent, and severity were associated with both past drought conditions and human activity $[4,5]$. Predisposing factors such as drought and weather combined with frequent (e.g., daily) human fire use (whether accidental or purposeful) made large areas prone to recurring fires. Approximately fifty percent of Wisconsin's vegetation and landscapes are estimated to have been influenced by Native American fires [6,7]. 
Depending on the ignition source, fire scars on trees can be viewed as both natural and cultural resources. In many forested ecosystems with hundreds, if not thousands, of years of human activity, a large proportion of basal injuries can result from human ignitions [8,9]. In the case where probability for anthropogenic ignitions is high, ecosystem conditions may be byproducts of human activity. Landscapes cultured by anthropogenic fire are recognized throughout North America [10-12].

Before about $1800 \mathrm{CE}$, reliable records of early human population, cultures, and fire are difficult to obtain or are unavailable for much of North America. In the Great Lakes region, early and literate travelers (Jesuits missionaries and French traders) provided records of population, culture, and trade [9]. These records are particularly important for understanding historical fire regimes since changes in populations and cultures often coincide with changes in fire frequency [10-12]. Thus, considering human history in analyses of fire regimes and fire ecology is imperative, especially in regions where anthropogenic fire has been deemed an important ignition source [12,13].

During at least the last three and a half centuries, historical records indicate that the Great Lakes region has been influenced by diverse cultures and population densities [14,15]. Generally, significant environmental changes occurred in response to cultures switching from subsistence to market economies [16]. In northern Wisconsin specifically, several Native American populations circa 1650 are estimated at 2000-3000 Menominee, several thousand Ojibwa, with additions by French and Indian 'fur traders' $[15,16]$. Driven by distant European markets, the trade of animal furs had an early and widespread influence on the number and locations of humans in this region [17]. Fire regimes changed in a multitude of ways during European settlement and development. Increased wildfire activity occurred, particularly along railways (due to increased ignitions embers from wood- and charcoal-burning railroad engines, sparks from railroad tracks, deliberate burning to clear lands by prospective farmers) while decreased fire activity occurred with EuroAmerican settlements (e.g., fuel alterations [6] and fire suppression) and continued to do so due to fire suppression policies $[18,19]$.

The primary objective of this study was to describe and quantify the historical fire regime characteristics in the Northern Sands Ecological Landscapes of Wisconsin [20]. The second objective was to examine the relative influences of climate and humans on fire regimes. We hypothesized that: 1) interactions between human ignitions and drought changed fire frequency and extent, and 2) fluctuating human populations, cultures interacting with 'climate' were major factors influencing fire occurrence over the last three and a half centuries.

\section{Data and Methods}

\subsection{Site Descriptions}

Study sites were established in the Chequamegon-Nicolet National Forest (CNNF), northern Wisconsin, USA (Table 1). Three sites were located in the Northeast Sands Ecological Landscape in Oconto County (Lakewood District) and one site was located in the Northwest Sands Ecological Landscape in Bayfield County (Washburn District) (Figure 1). The climate of northern Wisconsin is characterized as humid-continental with cold winters and warm summers [21]. The three eastern-most sites have a mean maximum temperature of $11.7^{\circ} \mathrm{C}$, an average annual temperature of $5.5^{\circ} \mathrm{C}$ and an annual precipitation of $83 \mathrm{~cm}$. The northwestern site is slightly cooler with a mean maximum temperature of $10.5^{\circ} \mathrm{C}$, an average temperature of $4.9^{\circ} \mathrm{C}$, and an annual precipitation of $84 \mathrm{~cm}$. Sites occurred on pitted outwash glacial deposits characterized by sandy and gravely soils [22]. The topography at all sites is variable with undulating glacial terrain and sandy outwash flats interspersed with lakes, ponds, and wetlands. Site areas ranged from 0.3 to $3 \mathrm{~km}^{2}$. 


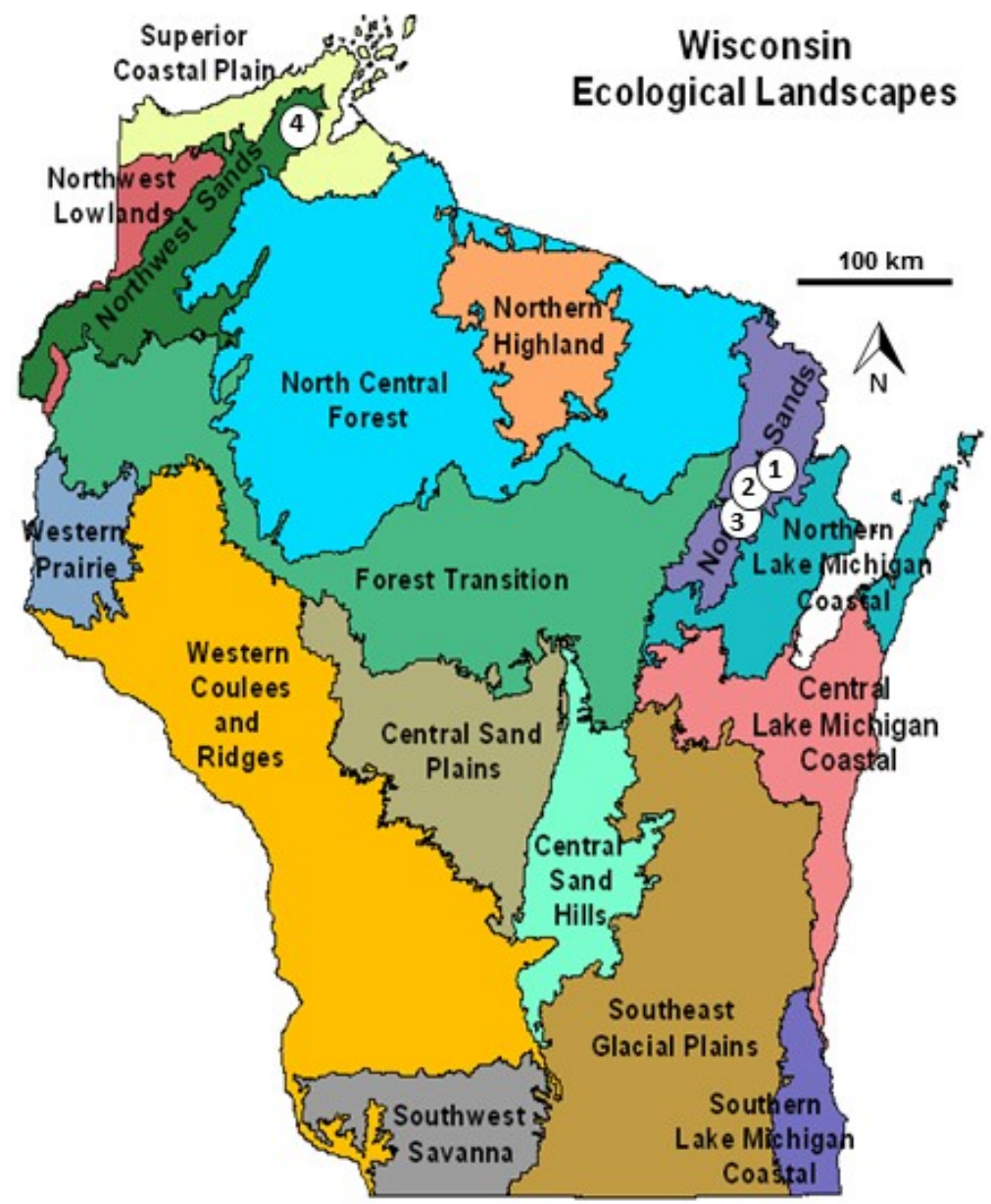

Figure 1. Locations of fire history sites (white circles) in Wisconsin's Ecological Landscapes [20]. Numbers in circles refer to site numbers in Table 1.

Table 1. Descriptions of site locations, vegetation, current dominate tree species, area, topography, and fire history records.

\begin{tabular}{|c|c|c|c|c|}
\hline Site name & Grindle Lake & Waubee Lake & Airport Road & Moquah Barrens \\
\hline Site number & 1 & 2 & 3 & 4 \\
\hline Tree species & Red pine & Oaks and $\mathrm{MH}$ & MH \& red pine & MH \& red pine \\
\hline $\begin{array}{l}\text { Community } \\
\text { structure }\end{array}$ & Woodland \& Wetland & Forest & $\begin{array}{l}\text { Forest, Woodland, } \\
\text { Wetlands }\end{array}$ & Woodland \& Forest \\
\hline & $\mathrm{N} 45^{\circ} 13.89^{\prime}$ & $\mathrm{N} 45^{\circ} 21.30^{\prime}$ & $\mathrm{N} 45^{\circ} 10.92^{\prime}$ & $\mathrm{N} 46^{\circ} 36.17^{\prime}$ \\
\hline Location & W $88^{\circ} 21.46^{\prime}$ & W $88^{\circ} 26.13^{\prime}$ & W $88^{\circ} 19.57^{\prime}$ & W $91^{\circ} 17.89^{\prime}$ \\
\hline Site area & $1 \mathrm{~km}^{2}$ & $0.3 \mathrm{~km}^{2}$ & $3 \mathrm{~km}^{2}$ & $0.6 \mathrm{~km}^{2}$ \\
\hline Topography & $\begin{array}{l}\text { Gentle slopes } \\
\text { and wetlands }\end{array}$ & $\begin{array}{l}\text { Hummocky terrain, } \\
\text { steep slopes }\end{array}$ & $\begin{array}{l}\text { Low hills, flatlands, } \\
\text { \& wetlands }\end{array}$ & $\begin{array}{c}\text { Steep \& } \\
\text { gentle slopes }\end{array}$ \\
\hline Number trees & 28 & 15 & 23 & 32 \\
\hline Number scars & 141 & 68 & 110 & 146 \\
\hline Number fire years & 25 & 24 & 23 & 27 \\
\hline Period of fire record & $1650-2008$ & $1638-1873$ & 1650-2009 & 1585-2009 \\
\hline
\end{tabular}


Three of the four study sites share similar current vegetation and site characteristics with pine and mixed-hardwood forest types growing on well to excessively drained, sandy outwash plains (Table 1). Somewhat differently, the Waubee Lake site has the greatest topographic variability and is presently a northern red oak (Quercus rubra) forest type with abundant red pine remnant wood (i.e., stumps, dead trees) but few living red pines. The Grindle Lake and the Airport Road sites have relatively gentle slopes, are interspersed with wetlands, and are more heavily covered in red pine. The Moquah Barrens site has the greatest relief and is adjacent to a large grassy area of jack (Pinus banksiana) and red pine barrens.

Historically, the four study sites had varied proximities to human activities associated with trading centers, camps, and villages. The Ojibwa (Chippewa) and other native peoples lived on Madeline Island about $40 \mathrm{~km}$ northeast of the Moquah Barrens site. About $1660 \mathrm{CE}$, French fur traders arrived in the region and by $1690 \mathrm{CE}$ a trade center at La Point, Madeline Island was established. The fur trade likely resulted in increased probability and distribution of anthropogenic ignitions. Although the northeastern study sites were further from Lake Superior trade routes [23], they were also within the trade network associated with Lake Michigan. These three sites (1-3; Table 1) are within $30 \mathrm{~km}$ of the present day Menominee Indian Reservation and $60 \mathrm{~km}$ from the Menominee River.

\subsection{Fire Scar Collection and Data}

Cross-sections from ninety-six fire-scarred red pine stumps, snags, and live trees were cut from the four study sites. Location (GPS coordinates), slope, and aspect were recorded for each tree sampled. Surfaces of cross-sections were sanded with successively finer sandpaper (80-1200 grit) until the cellular detail of annual rings and fire scar injuries was revealed. A radius (pith-to-bark tree-ring series) of the cross-section with the least amount of ring-width variability due to fire injuries was chosen for ring-width measurement and crossdating. Ring-width series from each sample were plotted and used for visual crossdating and signature year identification [24]. Visual matching of ring-width patterns allowed for the weighting of important "signature years" over years with low common variability among trees. Ring-width plots aided in identifying errors in measurement, missing rings, and/or false rings which can be associated with injury or drought. The samples and dating chronology were crossdated and verified using a master red pine chronology developed from the Cathedral Pines Natural Area (Oconto County; unpublished data) and live trees within the study sites. Computer program COFECHA $[24,25]$ was used to check the accuracy of crossdated tree-ring series. Fire scars were identified by the presence of callus tissue, charcoal, traumatic resin canals, liquefaction of resin and cambial injury. Calendar years of fire events represented the year of the tree's response to cambial injury. Fire events (year, season based on scar position) were recorded in standard FHX2 format [26]. Fire-free periods associated with red pine survival were estimated when possible.

\subsection{Reconstructed Drought Data}

Reconstructed Palmer Drought Severity Indices (PDSI) [27] during the period of the fire scar records were collated for use in analysis with fire events. Indices were averaged for the northern Wisconsin region (PDSI grid points: 198, 207, 215, and 216).

\subsection{AnthroFire Index (AFI)}

An AnthroFire Index (AFI) has been developed to detect changes in the fire regime that reflect human ignition influence [28,29]. The AFI was calculated using reconstructed drought [27] and fire occurrence data. The AFI operates under two assumptions concerning the relationship between drought and anthropogenic fires: 1) the absence of fires during drought years was due to a lack of human ignitions and, 2) the occurrence of fires in wet years resulted from increased human ignitions (accidental or purposeful). Assumption 1 relates to identifying the potential human ignition influence in an ecosystem and that, during drought conditions, fire probability is increased. Assumption 2 relates to fires occurring in 'wet' years; fires occurring in wet years are limited to burning during 
short, dry periods and require abundant or 'smart ignition' by humans. No human data (population, cultures, or others) are used in the AFI calculation and are limited to periods without modern fire suppression technology.

To calculate the AFI, fires occurring in wet years (PDSI $>0$ ) were assigned increasing values from 1 to 2.5 corresponding with increased wetness. Dry years (PDSI $<0)$ without fire were assigned decreasing values from -1 to -2.5 corresponding to increased dryness. Fire occurring in dry years (PDSI $<0$ ) and wet years without fire were not assigned values nor used. The time series of AFI values was then smoothed using moving averages of two lengths, 11 and 21 years, due to the irregular occurrence of AFI values through time and the need to include a sufficient number of observations to reduce spurious, short-term (e.g., $<4$ years) wet-dry variability. We scaled the AFI time series to a mean value of zero by subtracting the series mean. Thus, increasing AFI values were interpreted as increasing human influence ('smart ignitions') and decreasing AFI values were interpreted as decreasing human influence.

\subsection{Fire Extent Index (FEI)}

We developed a coarse-scale annual Fire Extent Index (FEI) to examine the relationship between drought and the potential sites burned and trees scarred [11,28]. The FEI was not developed for estimating the area burned but rather to estimate a relative spatial extent variable that could be related to PDSI. We calculated the FEI from data of the number of sites scarred in a year (range $=0$ to 4 , a value reflecting regional spatial extent of fire in a year) and the percent of trees scarred at a site (range $=0-90$, a value reflecting the scale of fire severity at a site). The FEI is the product of the number of sites scarred and the percent of trees scarred at all the sites (Equation (1)).

$$
\text { FEI for year } x=\# \text { fire }- \text { scarred sites } x \% \text { trees fire }- \text { scarred }
$$

\subsection{Fire Scar Data Analysis}

For each site we summarized fire event data including ranges of fire intervals, mean fire return intervals, seasonality of fires, and fire severity (based on percentages of trees scarred) [30,31]. Data summaries were developed for the full periods of records and for sub-periods separated based on known changes in the fire environment (e.g., humans, climate, land use). The quality of the fire scar record can vary by the size of the site area and the number of recorder trees in the record at any time. We estimated the effects of sample size on fire frequency by comparing the decade-to-decade relationship between sample depth and the number of fire years detected. The asymptote of the relationship between sample depth and number of fire years was assumed to be an indicator of the sample depth required to adequately characterize fire events (i.e., quality of the fire scar record at any year).

Correlation analysis was used to determine if PDSI was significantly related to fire frequency, percentage of trees scarred, or the FEI. Regression analysis was conducted to relate PDSI to FEI and develop a model predicting variability in the FEI [31]. FEI was transformed utilizing a natural log prior to regression analysis to adjust for the non-linear relationship with PDSI. SAS/STAT software [32] was used for statistical summaries, analysis of means, and regression and correlation analyses. We collated nine other existing fire scar records from the Great Lakes Region $[5,13,29,33]$ and compared them to the northern Wisconsin fire scar record. Comparisons among sites included regional fire years (years in which many sites burned), percent trees scarred, and the FEI. In addition, we compared the fire frequencies derived from the study sites with those predicted by a model of historic fire frequency based on climate parameters [34]. 


\section{Results}

\subsection{Fire Scar Data}

We dated a total of 465 fire scars on 98 red pine remnant and living trees from the four study sites (Table 1). Ninety percent or more of the fire scar years was captured by as few as 11 trees (Figure 2). Fire scar dates spanned the period 1591-1948 (Figure 3). The number (and extent) of fires was lowest from 1665 to 1718 and highest from 1719 to 1820 . Prior to 1780 , mean fire intervals ranged from 8.9 to 29 years at all sites (Table 2). The four most frequently occurring fire years were 1664, 1743, 1756, and 1780 (i.e., occurring during the fur trade era and prior to EuroAmerican settlement). The occurrence of fire scars decreased sharply in the 1920s (Figure 3). In the pre-EuroAmerican settlement period (1650-1864), about 25 percent of the years had a fire recorded in at least one study site (Figures 3 and 4). Of these 54 fire years, 30 occurred during drier years (PDSI $<0)$ and 24 occurred during wetter years $($ PDSI $>0)$.

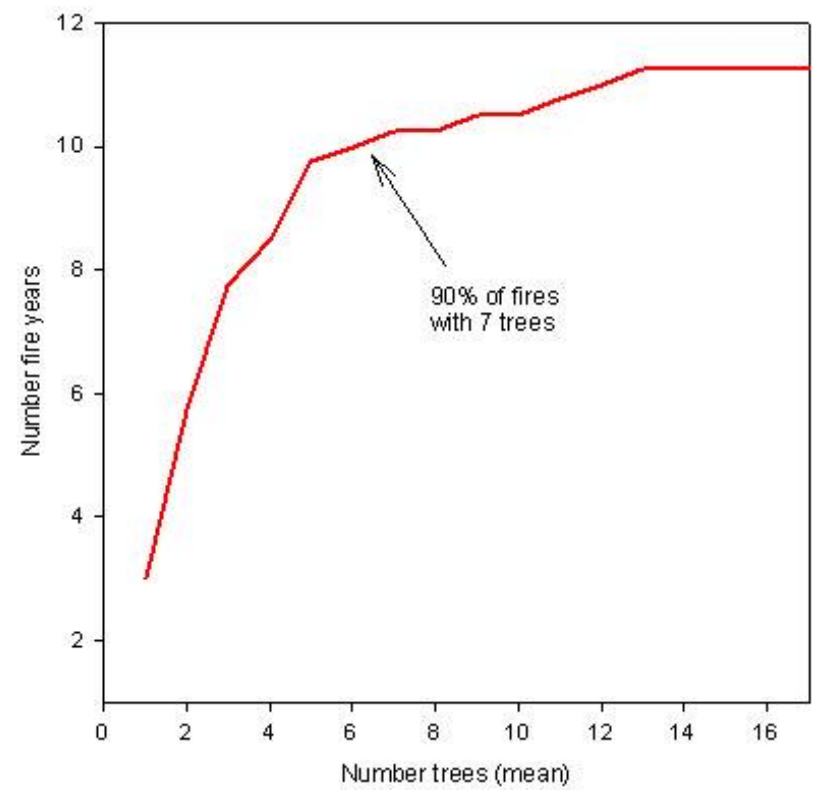

Figure 2. Relationship between the number of trees sampled and new fire years detected based on data collected at the four study sites. The beginning of the asymptote of the curve reflects the minimum sample depth needed in a given area for a high-quality fire scar record. 


\section{Grindle Lake}

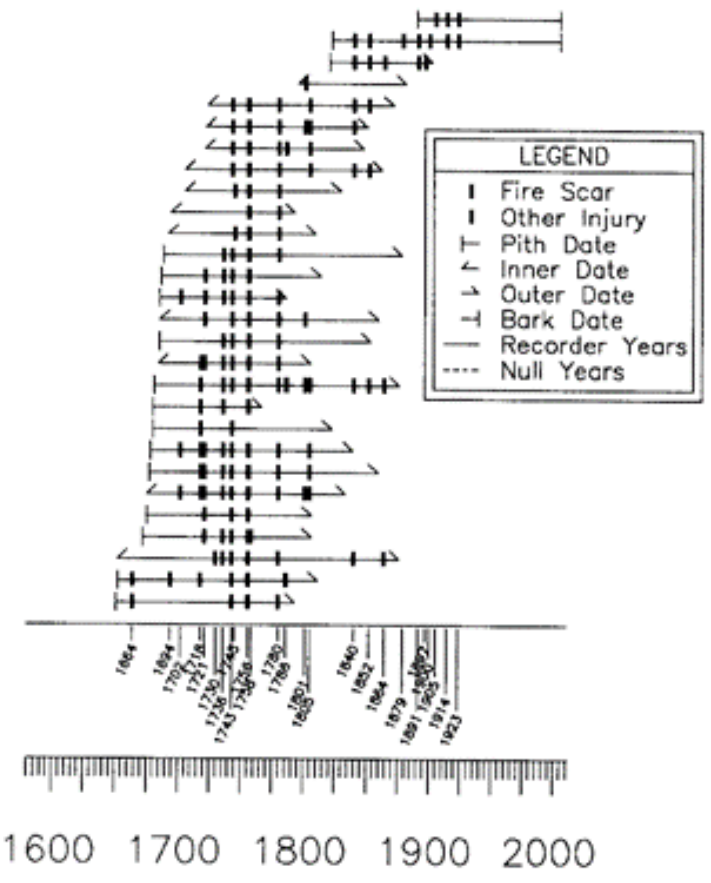

Airport Road

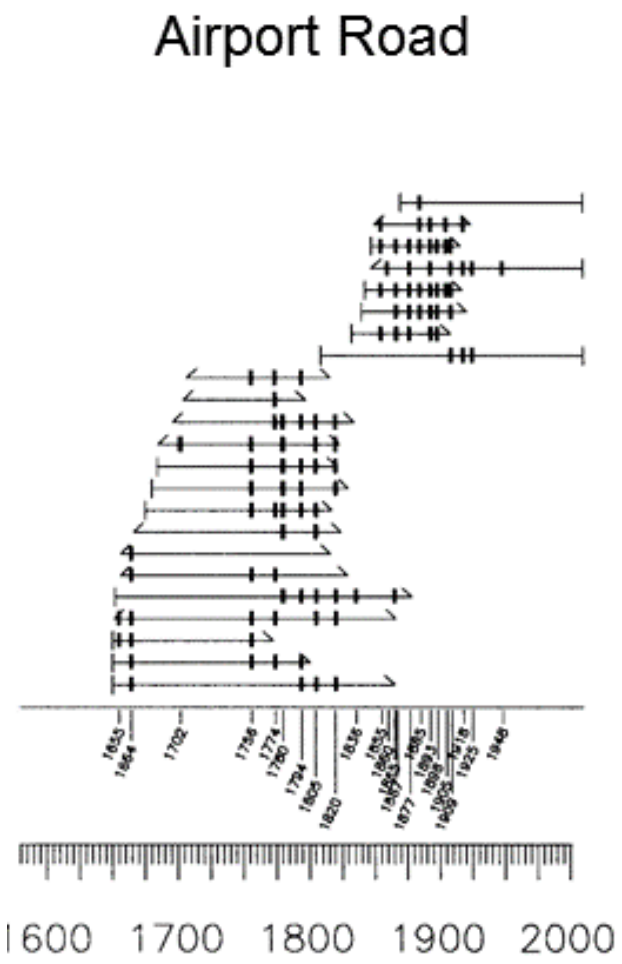

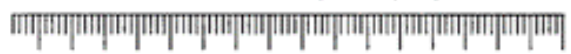

\section{Waubee Lake}

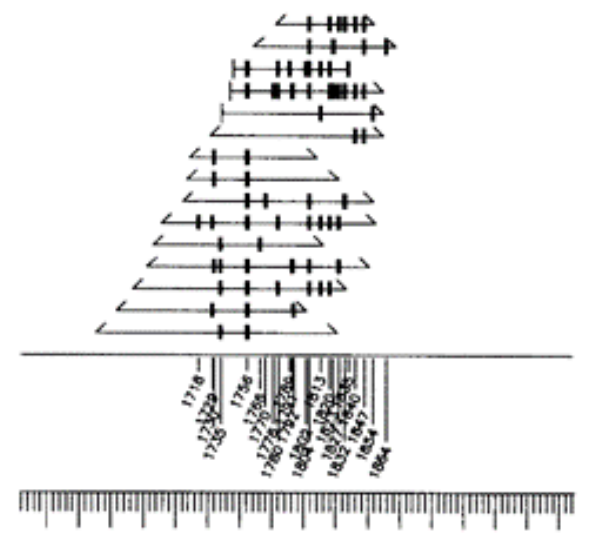

16001700180019002000

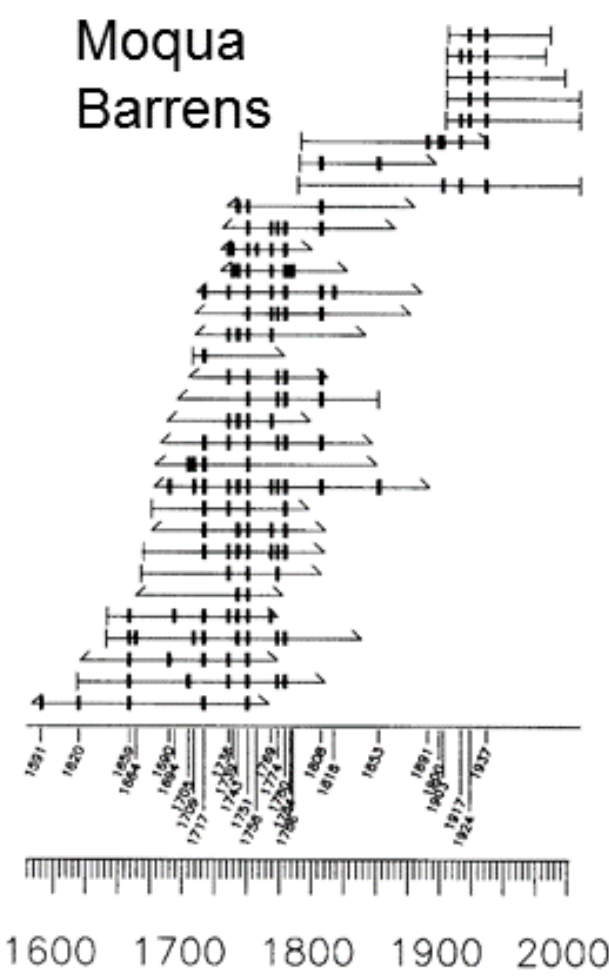

Figure 3. Fire history diagrams showing fire scar dates (vertical short lines) and composite fire scar records (bottom line with dates) at the four study sites. Each horizontal line represents the tree-ring record of a red pine remnant or living tree. 


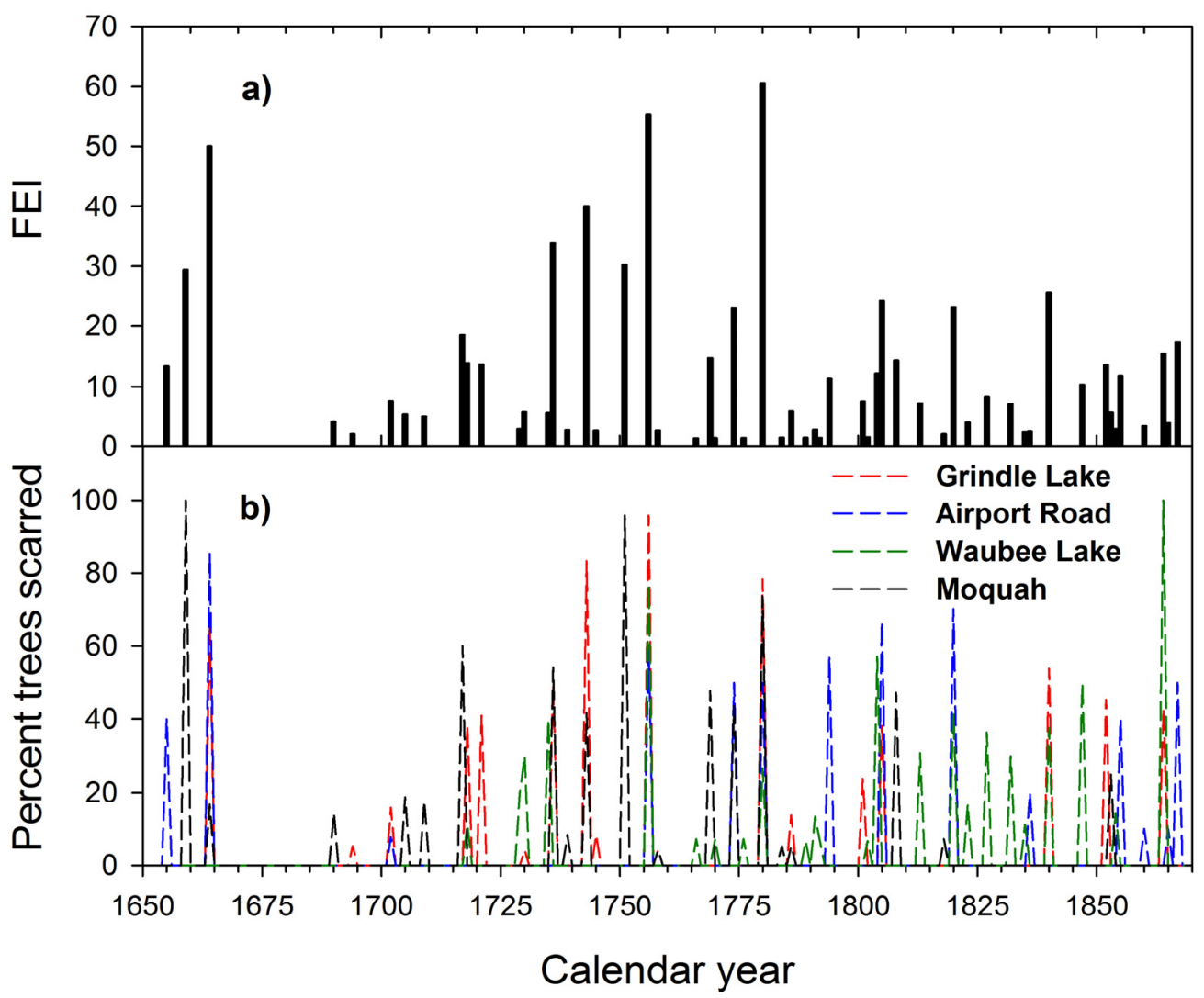

Figure 4. (a) Bar plot of the Fire Extent Index (FEI) for Sands Ecological Landscapes of Wisconsin ( $n=98$ red pine trees), (b) percentage of trees scarred at each of the four study sites through time.

Table 2. Fire frequency statistics for study sites. Time periods were selected based on characteristics of fire frequency, human history, and fire history record overlap. Precise time periods vary slightly owing to fire intervals that span the boundaries between time periods. Model predicted MFIs (2nd to last row) are from Guyette et al. 2012. Periods not covered by the fire scar record are represented by "na".

\begin{tabular}{ccccc}
\hline Period & Grindle Lake & Waubee Lake & Airport Road & Moquah Barrens \\
\hline $\begin{array}{c}\text { Mean fire interval } \\
(\sim 1660-1780)\end{array}$ & 9.7 years & 9.9 years & 29.0 years & 8.9 years \\
$\begin{array}{c}\text { Mean fire interval } \\
(\sim 1780-1864)\end{array}$ & 12.0 years & 5.1 years & 14.4 & 14.6 years \\
$\begin{array}{c}\text { Mean fire interval } \\
(\sim 1852-1925)\end{array}$ & 10.1 years & na & 6.4 years & 14.2 years \\
$\begin{array}{c}\text { Mean fire interval } \\
(\sim 1925-2010)\end{array}$ & $>87$ years & na & $>44$ years & $>43$ years \\
$\begin{array}{c}\text { Mean fire interval } \\
(\text { start to }<1937)\end{array}$ & 10.4 years & 6.3 years & 12.9 years & 12.8 years \\
$\begin{array}{c}\text { Mean fire interval } \\
(\text { climate model }\end{array}$ & $1664-1923$ & $1707-1864$ & $1655-1925$ & $1591-1937$ \\
$\begin{array}{c}\text { predicted MFI }[33]) \\
\text { Range of pre-1925 } \\
\text { intervals }\end{array}$ & $2-35$ years & 3-21 years & $2-54$ years & $2-35$ years \\
\hline
\end{tabular}

Fire scar seasonality was determinable for 316 scars (68 percent of scars). Dormant season (between growth rings) fire scars were the most common among sites with the exception of the Airport Road site which had more growing season fires than dormant season fires (Table 3). For all sites combined, 65 percent of the fires occurred during the dormant season (inter-ring and early earlywood 
scars), whereas 35 percent occurred during the growing season (middle earlywood, late earlywood and latewood scars; Table 3). Mixed seasonality fires (i.e., individuals years with trees recording different seasons of fires at a site) occurred during several years at three of the sites (Table 3). The dramatic fire year of 1780 [4] had the highest variability in fire seasonality both within and between sites.

Table 3. Fire scar positions within annual rings and their related fire seasonality. Season of fires are the percent of scars in each scar class.

\begin{tabular}{|c|c|c|c|c|c|}
\hline & Grindle Lake & Waubee Lake & Airport Road & Moquah Barrens & All Sites \& Years \\
\hline \multicolumn{6}{|c|}{ Scar location within annual ring } \\
\hline $\begin{array}{l}\text { Between rings } \\
\text { (dormant season) }\end{array}$ & $52 \%$ & $88 \%$ & $10 \%$ & $72 \%$ & $56 \%$ \\
\hline Early earlywood & $24 \%$ & $0 \%$ & $7 \%$ & $6 \%$ & $9 \%$ \\
\hline Middle earlywood & $16 \%$ & $0 \%$ & $17 \%$ & $3 \%$ & $9 \%$ \\
\hline Late earlywood & $5 \%$ & $0 \%$ & $22 \%$ & $1 \%$ & $7 \%$ \\
\hline Latewood & $3 \%$ & $12 \%$ & $43 \%$ & $17 \%$ & $19 \%$ \\
\hline \multicolumn{6}{|c|}{ Season of fire } \\
\hline $\begin{array}{l}\text { Late fall, winter, \& } \\
\text { early spring scars }\end{array}$ & $76 \%$ & $88 \%$ & $17 \%$ & $79 \%$ & $65 \%$ \\
\hline $\begin{array}{l}\text { Late spring \& } \\
\text { summer scars }\end{array}$ & $24 \%$ & $12 \%$ & $83 \%$ & $21 \%$ & $35 \%$ \\
\hline $\begin{array}{l}\text { Mixed seasons fires } \\
\text { at site (percent and } \\
\text { number years) }\end{array}$ & $29 \%, 5$ & $0 \%, 0$ & $16 \%, 3$ & $5 \%, 1$ & $12 \%, 2$ \\
\hline
\end{tabular}

\subsection{Tree Age and Recruitment}

The youngest ages of red pine trees surviving fires ranged from 6 to over 30 years. The average age of trees at time of first scar was 15 years. Red pine overstory recruitment appeared to have occurred primarily as single trees or in small groups. However, at least two sites had two periods of major regeneration and recruitment, indicative of major disturbance. At Grindle Lake 52 percent of the trees sampled had established circa 1670-1685 and at the Airport Road site 44 percent of the trees were established circa 1660.

\subsection{Fire Extent Index and Climate}

Reconstructed drought indices [27] were a better predictor of the FEI than fire interval length. The FEI was highest during drought years (PDSI < 0). However, between 1650 and 1864 (i.e., the most replicated period of record) about 70 percent of drought years had no evidence of fire. When fires did occur $(n=54$ years), drought (PDSI) explained about 24 percent of the variance in the FEI (Equation (2), Figure 5). A model predicting the FEI as a function of drought for fires years between 1650 and 1864 was given as:

$$
\operatorname{Ln}(\mathrm{FEI})=1.84-(0.32 \times \text { PDSI })
$$

where: $\ln (\mathrm{FEI})=$ natural $\log$ of (Fire Extent Index), PDSI $=$ reconstructed drought [27] $, n=54, r^{2}=0.23$, $p<0.001$ for model and variable.

Based on the FEI, fires in 1780, 1774, 1756, and 1664 were extensive. These years were dry with the exception of 1756 . The year 1756 was incipient wet $(\mathrm{PDSI}=0.98)$ and fire scars were limited to the northeastern sites (\#'s 1, 2, 3; Table 1). The average PDSI of the fire years 1780, 1774, and 1664 was -1.9 (mild drought). 


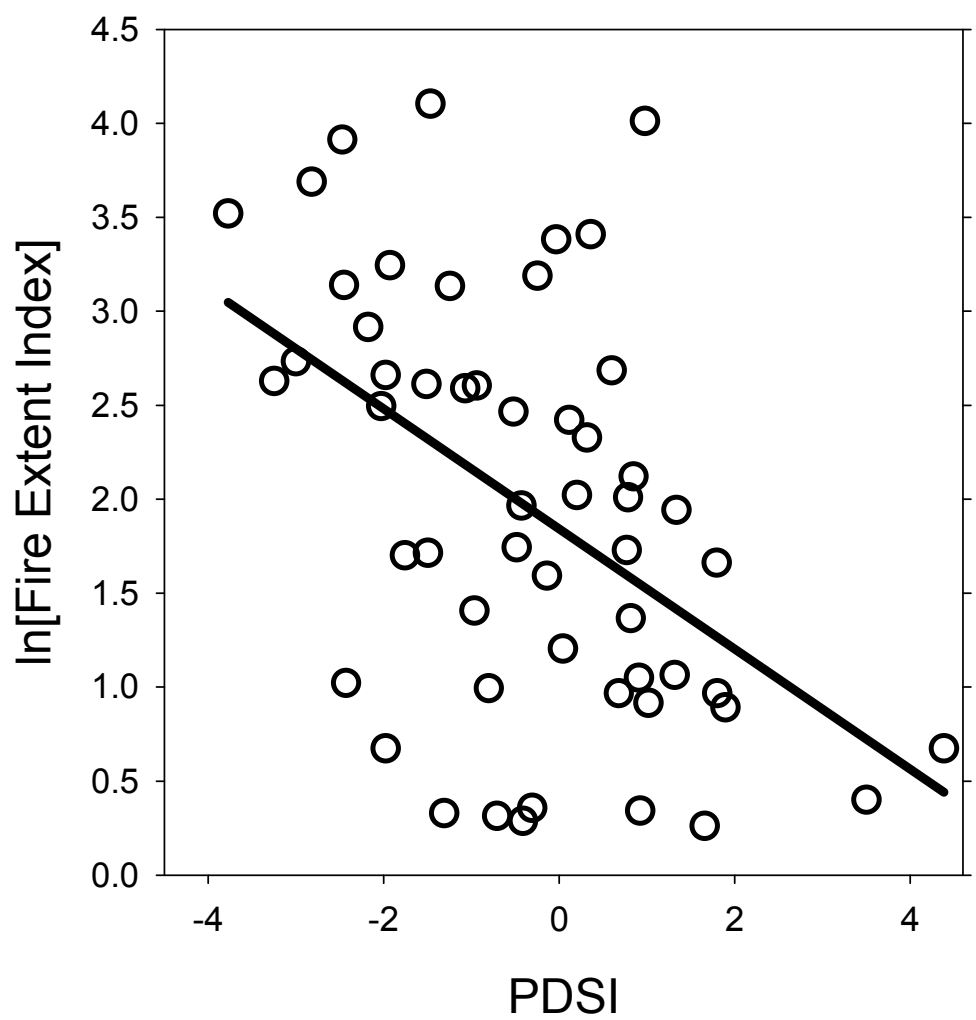

Figure 5. Scatterplot of the Fire Extent Index (FEI) and reconstructed Palmer Drought Severity Index (PDSI) for 54 historical fire years in the Northwest and Northeast Sands Ecological Landscapes of northern Wisconsin (Figure 1). Data are from the period 1660-1864. The regression indicates prediction of FEI from reconstructed drought $\left(\ln (\mathrm{FEI})=1.84-(0.32 \times \mathrm{PDSI})\right.$, Equation $\left.(2), r^{2}=0.23\right)$. Decreasing values of PDSI relate to increasing dryness.

\subsection{Human Population, Culture, and Fire Frequency}

Native American populations plummeted soon after European encounters. In 1634, Jean Nicolet [35] wrote 'Already in 1644, the smallpox had reached the Winnebago in Green Bay where the rotting corpses caused great mortality and they could not bury the dead' [36]. Although we identified few fire years before the 1660s, this could be partly due to the reduced sample size in the record. The study fire regime, as described by the AFI (Figure 6), was increasingly influenced by humans from 1660 to 1755 after Native American populations increased upward as the Fox and Sauk immigrated to northern Wisconsin [36]. Continued human land use in the region occurred from 1755 to 1860, but was interrupted with short decadal decreases in circa 1775-1785 and 1810-1825 (Figure 6a). The lowest levels of the AFI occurred during 1770s and 1780s and corresponds with the "Great Smallpox Epidemic of 1775-1782" [37] and the population recovery thereafter. 


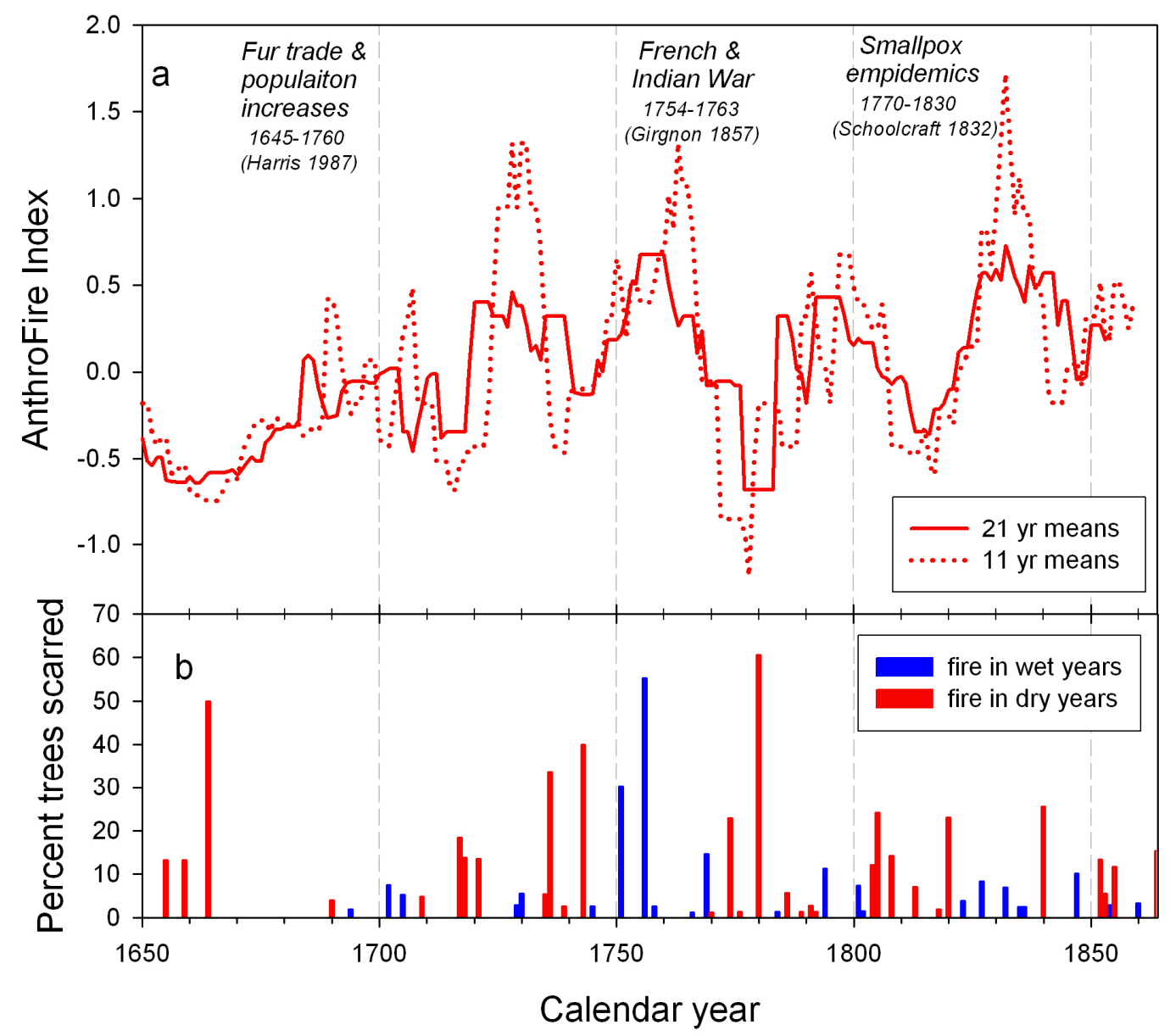

Figure 6. (a) Running means (21- and 11-year) of the AnthroFire Index (AFI). Larger AFI values indicate increasing human influence based on the occurrence of fire in 'wet' years and the absence of fire in drought years. The text identifies possible factors and periods of regional human influence in the fire regime of Northeastern Sands Ecological Landscape [23,38,39]. (b) Time series of the percent of trees scarred and reconstructed drought conditions (blue for wet years (PDSI $>0$ and red for dry years PDSI < 0).

Early trends of increased fire frequency were associated with increased human population density, movement, and trade. Shipping records of the tonnage of trade goods in and out of the Great Lakes Region [23] were associated with fire frequency during the period 1640 and 1785 (Figure 7). The significance of the relationship between fire and trade could not be tested due to autocorrelation in the time series data and the lack of independence of the observations in trade records. Perhaps the most profound change in the fire regime occurred after 1925 when fire frequency was diminished to a rate of only two fires in an 85-year period ( $<0.6$ fires per 25 years). Despite the low number of sample trees during this period, the fire record is fairly accurate because of the abundance of younger trees and trees not sampled (they had no fire scars) and the observation that 11 trees should capture much of the fire record (Figure 3). 


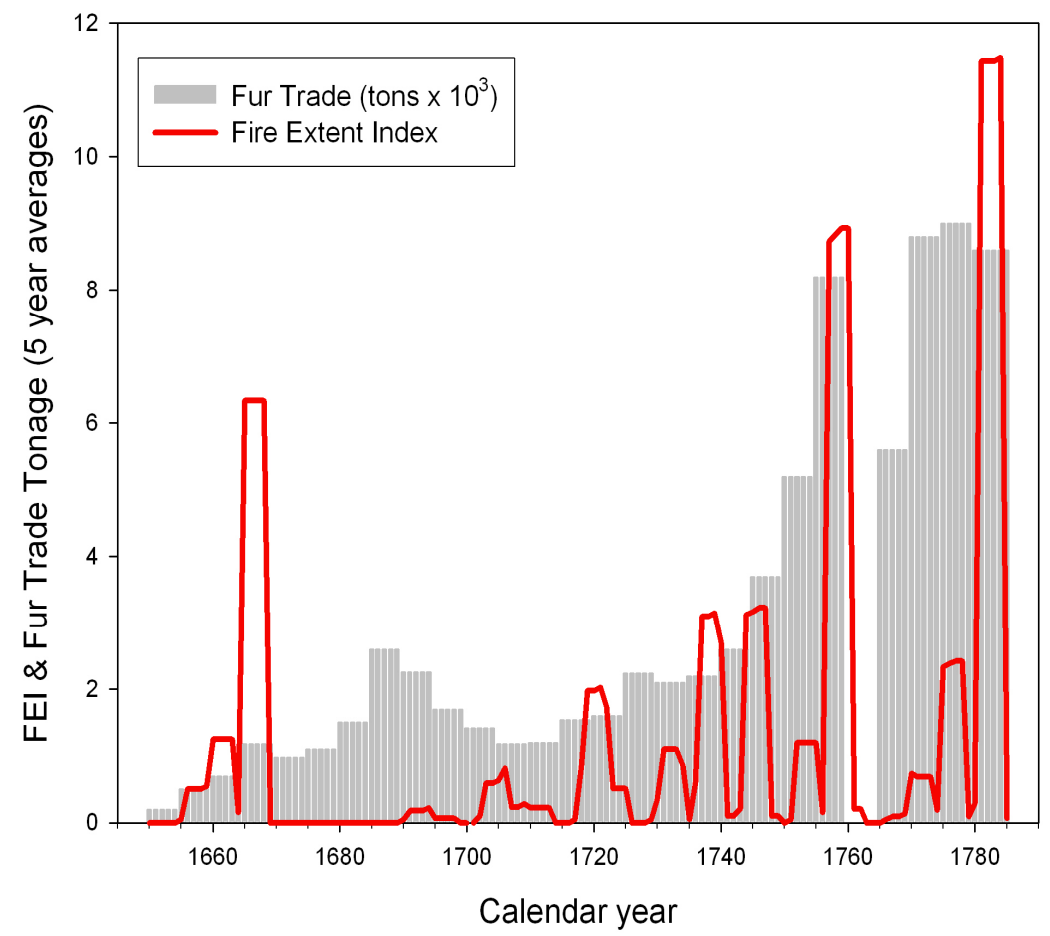

Figure 7. Trends in Great Lakes fur trade per five-year period [23] plotted with a five-year moving average of the number of fires at the study sites. The 1760-1765 trade data is missing from Harris [23]. The similar trends in trade and fire regimes support the 1650-1785 increase in human influence as calculated by the AnthroFire Index.

\subsection{Climate-Fire Comparison in Other Fire History Records}

We compared the northern Wisconsin fire scar record with nine fire scar records from the Great Lakes Region $[5,13,29,33]$. The synchrony of years reveals the probable influence of large-scale climate influence on regional fire activity (Figure 8). The temporal and spatial synchrony of percentage of trees scarred is significant $(r=0.55, p<0.01)$. Curiously, fire scar records outside of northern Wisconsin, but in the Great Lakes region, are a stronger predictor of fire in Wisconsin than reconstructed drought [27].

Estimates of historical fire extents were based on the FEI (Figure 7); an index developed from a spatially limited $\left(<6 \mathrm{~km}^{2}\right)$ collection area. In an attempt to overcome this limitation and to add support or refute extrapolating the characteristics of Wisconsin fire record to larger spatial extents, we compared the Wisconsin fire records to historical fire records in the Midwest and Great Lakes regions. Many of the years calculated as having large FEI values in northern Wisconsin were also extensive fire years in more northerly and eastern regions. For example, in 1780 all sites in Wisconsin burned and three of seven sites (43 percent) were burned in the Huron Mountains of Michigan $(175 \mathrm{~km}$ northeast) [28]. Similarly, in 1664 fires also coincided in the Huron Mountains and in Wisconsin. 


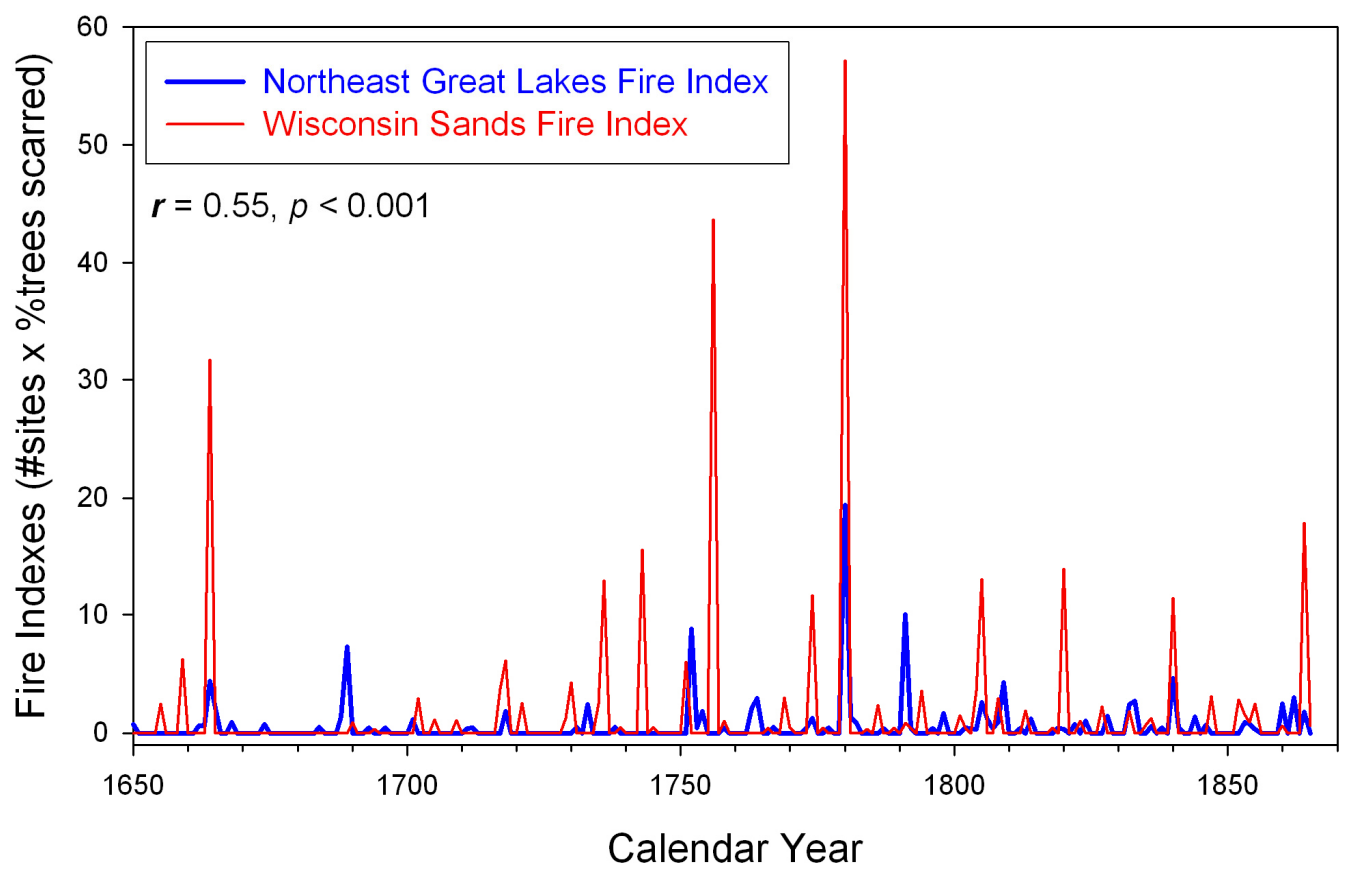

Figure 8. Comparison of the fire records from the Northwest and Northeast Sands Ecological Units of northern Wisconsin (98 trees, this study) plotted with separate fire records in the Great Lakes region including Ontario, Upper Peninsula of Michigan, and Minnesota (239 trees). Correlation analysis includes all years. Removal of no fire years increases the correlation coefficient.

In 1780, 9300 hectares were estimated to have burned in the Ontario's Algonquin Park Barron Township along with other fires in the eastern Algonquin Highlands [4,5,32]. The 1780 fire year is also represented $150 \mathrm{~km}$ northwest in northern Minnesota [40] and other areas [41]. Remarkably, 1000 kilometers to the south, sites across Missouri, Arkansas, and Oklahoma (an estimated 56 percent $\left(122,000 \mathrm{~km}^{2}\right)$ of the Ozarks Highlands) burned in 1780 [11]. Fires in these studies are hypothesized to have resulted from the interactions between human ignitions and drought.

Mean fire intervals from northern Wisconsin sand ecosystems (Table 2, data rows 1 and 2) tend to be shorter than climate modeled fire intervals for the region (PC2FM [33], Table 2, data row 6). Two of the Wisconsin fire history records (Grindle and Waubee Lakes) were included in a dataset of 170 North American sites used to construct and calibrate this model [33]. Generally, mean fire intervals in this study (Table 2, data rows 1 and 2) are from 5 to 11 years shorter than this climate model estimates. This difference may result from more frequent human ignitions or landscape influences such as reduced topographic roughness.

\section{Discussion}

\subsection{Fire Intervals}

Red pine stumps, snags, and trees provided a fire scar record spanning three centuries. The length and quality of fire records provided by this wood was comparable to fire histories from Ontario, Michigan, Minnesota, and Wisconsin [18,41-45]. The fire scar record that the northern Wisconsin remnant wood provides is decaying and will probably be unavailable in a few decades. Much of the remnant wood used in this study was sampled near ground level with decay advancing from the stump top. Because sample trees were not randomly located and represent a small portion of the landscape, the detection of small fires may be less well represented than that of larger fires.

Fire intervals were more temporally variable within sites (Figure 3) than between them (Table 2). We hypothesize that this indicates strong local fire control (probably ignition abundance) on the study 
sites. For example, the Airport Road site, with the exception of a single fire scar (1702, growing season) had a 92-year fire interval (1664-1756). Also, drought explained only about one quarter (23 percent) of the variance in fire extent. This could be due to strong anthropogenic ignitions during windy and dry weather. The short length of the fire intervals at the Waubee Lake site may also be due to relatively high human activity. As is the case in many areas of the U.S., the greatest change in MFI at the sites resulted from fire suppression after about 1910. This is probably the most radical change from the historical fire regime in the record. Although this period appears low on fire scar data, during field collection we observed an absence of fire scars or charcoal on thousands of younger live trees ( $<100$ years in age) across all sites indicating that few if any recent fires had occurred.

Most fires were likely single event fires with short durations (a few days as opposed to months). This conclusion is based on the consistency of fire scar positions within the dated annual rings when compared among different trees at the study sites. Little is known about the causes of fire years with mixed seasonality of fire scar positions. We surmise that this indicates either variability in the timing of fires or a difference among trees in the timing of wood formation and dormancy (Table 3). Scar seasonality differences within a year at a single site may indicate that fire burned very slowly, burned as ground fires (the study sites often included small areas of peat) that "flared up" again throughout the dormant and growing seasons, or there were multiple fires within a site within the year.

Often, intra-ring fire scar seasonality data has limitations due to the unknown differences in the timing of wood formation among trees and through time. Additionally, the effects of site conditions on the timing of cambial dormancy and physiology account for differences in the timing and rates of wood formation among trees. The timing of historical fires at Waubee Lake appears unique based on the preponderance of dormant season fires (88 percent, Table 3). Several factors unique to this site may be important. First, the fire history data are from red pine remnants scattered within a forest currently dominated by northern red oak (Quercus rubra). If this site was dominated by oak during the period of fire record, then deciduous leaf litter may have promoted dormant season fires. However, the composition of the prior stand is in question as northern red oak has benefitted greatly in northern Wisconsin since European settlement [19]. A second hypothesis is that Native Americans were actively using the site and conducted dormant season burns for their benefit such as harvesting acorns in the fall [46]. Dormant season and frequent burning could also have been used to promote the growth of nearby extensive areas of blueberries [47]. A trading post located at Waubee Lake in the mid-1800s and an early Native American presence in the region make it probable that abundant anthropogenic ignitions existed which would have been necessary to maintain frequent fire in the hummocky topography of the site.

\subsection{Climate, Humans, and Fire}

During fire years, the best predictor of fire severity (i.e., percentage of trees scarred during fire events) and extent of fire at the study sites was drought [27]. However, reconstructed drought was a poor predictor ( $<0.06$ percent variance explained) of percentages of trees scarred alone. From this, we infer that between 1650 and 1864 the fire regimes of the study region were in an ignition-limited stage [10] and that fire frequency was primarily controlled by non-climatic factors such as ignition frequency.

Through time, the fire scar record defines a fire regime that had strong but variable anthropogenic influence. Compared to fire frequencies of other eastern and southern fire regimes [33], study sites had a higher frequency of fires than might be expected based on climate conditions (temperature and precipitation). As has been found elsewhere, anthropogenic influences on the fire regimes are expected to have been caused by multiple factors such as changes in human population density, cultures, and values. In northern Wisconsin, changes in commerce, land use, war, conflict, material culture, and even spirituality likely influenced the fire regime. Ignitions from flint and steel were brought to northern Wisconsin by Jesuit missionaries in the early 17th century as documented by Jean De Brebeuf in 1633 [48]: "You should love the Indians like brothers, with whom you are to spend the rest of your 
life. Never make them wait for you in embarking. Take a flint and steel to light their pipes and kindle their fire at night...".

The French fur trade and material culture developed quickly with the European religious missions. Material culture soon increased in influence over the religious mission, the fur trade soon dominated, and the Jesuits were expelled for a time (1712-1738) during the Fox Wars [36]. The material culture driven by the economics of the fur trade (Figure 8) and fire technology of Europe (e.g., flint and steel, rifles, metal pots) modified the fire regime and resulted in new human trails beyond the traditional waterways and into the "wilderness". During the most replicated period of our fire history data (1650-1864), commerce in the northern Wisconsin economy was centered on the fur trade. For over 200 years, the European demand for furbearers, especially beaver, likely affected ignitions (i.e., rates, seasons). In summary, in northern Wisconsin this period of the fire regime may have been influenced by climate conditions and commercial activity including the politics and material demands from Europe.

Early commercial activities influencing the fire regime include the increased movement of humans (and potential ignitions) during the fur trade. In this case, ignitions may have occurred in remote regions (i.e., low human population density) where beaver and their habitats were abundant. Fires may have been set to alter habitat for beaver and other furbearers $[49,50]$ and encourage an increase small woody (e.g., willow, birch, aspen) and herbaceous vegetation that are a primary source of food for beaver and other wildlife. By the 1820s, overharvesting of beaver in northern Wisconsin began to reduce the fur trade and perhaps ignitions. Beginning in the 1850s, land use in northern Wisconsin changed to include extensive commercial activities (i.e., 'The Great Cutover') [51] of logging and agriculture. Vegetation conversion with fire and axe altered the fuel environment (fuel types, fuel fragmentation, and fuel loading) while human population density continued to increase.

Movements of human ignitions can create complex, abrupt, and potentially rapidly changing characteristics in fire regimes and vegetation [11]. Although many native cultures had remarkable abilities to travel, few had the transport technology of the Ojibwa birch-bark canoe [52]. Canoes allowed travel for trade and the migration of human populations. Native American oral histories indicate long-distance movements by water of tribal groups from east to west during the early period of European contact. Ojibwa tradition indicates that they lived near the Saint Lawrence River and about 1660 C.E. the Ojibwa migrated westward in the Great Lakes region [53]. Early population shifts of humans with 'intelligent ignitions' (i.e., ignited through a thought process) may have altered the vegetation of the study region with a design of subsistence fire use.

Primary among Ojibwa was the use of paper birch (Betula papyrifera) bark. The bark was incorporated into shelter (i.e., hogans) and canoe construction, thus, incentive for burning existed to increase this critical resource when and where it was needed [52]. Paper birch is a shade intolerant early successional tree species that requires bare mineral or organic soil for seedling reproduction [54,55], conditions that are enhanced by fire. Forest canopy and litter disturbance such as that from fire are accountable for the establishment of many stands. In addition, Native Americans had many other reasons for manipulating vegetation for their use and benefit.

\subsection{Human Conflict, War, and Fire}

The Potawatomi, Ojibwa, Sauk, Fox, and Ottawa groups moved into Wisconsin as early as the 1600s, near the beginning of our fire history. The early fire history of Wisconsin cannot be separated from war and conflict among the cultural groups, commercial enterprises, and the societies that lived there. Fire has long been a tool of war and conflict [56,57]. Groups that vied for power, land, furs, influence, and 'souls' included the Menominee, Sioux, Ojibwa, French, English, Americans, and Jesuits. Many conflicts occurred in Wisconsin during the Iroquois-French wars ( 1701), Fox Wars (1712-1738), the French and Indian War (1754-1763), and the War of 1812 [36]. Generally, with the exception of the French and Indian War, these conflict periods do not appear to be associated with changes in fire regime characteristics, even despite new Native American groups moving into Wisconsin as a result. 
Characteristics of fire scars in 1756 suggest that it may be pronounced due to the 'French and Indian War' (1754-1763) or 'Seven Years War'. During the War, the Menominee and others were allied with the French while the Iroquois were allied with the British. The year 1756 is an extreme outlier because of a high proportion of trees scarred (55 percent), sites with fire (3), and occurrence during incipient wet conditions (PDSI +0.98) [27]. Over the full period of the fire scar record, 1756 ranked third in numbers of fire scars. In the Northeastern Sands Ecological Landscape of Wisconsin (near present Menominee tribal lands), 81 percent of the trees were scarred in 1756. Alternative hypotheses for the magnitude of the 1756 fire year are 1) weather, not summer season drought conditions, was the major and sole factor for the pronounced fire year, and/or 2) the interaction of weather and abundant human ignitions were predisposing and inciting factors.

\subsection{Diseases and Population}

Perhaps a greater factor affecting anthropogenic fire regimes than wars or conflicts was the devastation of Native American populations by diseases introduced from Europe. Disease has been linked to depopulations and changes in fire activity at multiple sites [5,10]. Jean Nicolet visited thousands of the Ho-Chunk in Wisconsin in 1634 [57]. Twenty years later, French fur traders found only 700 people remaining. In northern Wisconsin, smallpox was introduced by Europeans in the mid-1600s and continued as a serious episodic epidemic until at least the 1830s [34,58,59]. The later medical history of smallpox among the Ojibwa indicates that this disease was brought by British fur traders in 1770. We observed declines in the AnthroFire Index (Figure 6) circa 1780 and 1830 coincident with documented smallpox out breaks further implicating humans in regional fire activity.

Although written history rarely provides the data needed for systematic analysis, it does provide important context to the fire scar data. Hunting and gathering activities often utilize landscape-scale fires. Studies on hunting patterns and fur trade of Native Americans document human locations, timing, and activities [36]. Kay [36] references European's first encounter with the Menominee Indians at the mouth of the Menominee River (south of sites 1-3). By 1720, sites 1-3 may have been influenced by the Menominee, Fox, and Sauk (see Figure 1 in [36]).

\subsection{Management Implications}

Knowledge of fire history is often a first step in ecosystem restoration activities that incorporate fire management. Data of historical fire intervals, severity, and extent provides a wealth of information for consideration in management. Paired with knowledge of species and ecosystem ecology, past vegetation composition, structure and change may be realized. The historical range of variability in fire disturbance provides a sense for landscape dynamics through space and time [1]. Coupled with other historical and ecological information, such as Public Land Survey notes [60], county records, aerial photography, soil surveys, and ecological land type maps, it is possible to set targets such as forest patch sizes, structure diversity, and stem density. In red pine and oak forest ecosystems, fire intervals and tree regeneration and successful recruitment may be linked to fire. Identification of extreme fire events and their inciting factors (e.g., drought, humans) can be important examples beyond the potential future management opportunities.

\section{Conclusions}

Fire histories developed from fire scars are capable of revealing numerous and varied details of the long-term changes in fire, forests, and land use that are otherwise unobtainable by other methods. We expect these fire history data and analyses provide land managers, fire practitioners, policymakers, and the public a greater perspective on the ecology and historical role of fire in northern Wisconsin. In northern Wisconsin Sands Ecological Landscapes, fires were highly variable through time, ranging from uncommon to frequent and spatially limited to extensive. A temporal understanding of fire regimes aids in realizing not only factors that influence fire but also the full range of potential fire conditions. In the Lake States, historical fire events are among the most powerful and dangerous 
(rate of spread, energy release) experienced in the U.S. (e.g., 1871 Peshtigo Fire, 1980 Mack Lake Fire) [61]. From the current network of fire history data in the Great Lakes region and expansive unstudied areas, high potential exists to further describe the landscape variability in historical fire frequency and, specifically, the climatological conditions associated with high severity fire event years (ex. 1664, 1756, and 1780).

Acknowledgments: The Northern Research Station of the USDA Forest Service provided funding for this project. Support for location, collection, and historical information was provided by the Chequamegon-Nicolet National Forest. Greg Nowacki provided helpful comments on previous versions of the manuscript.

Author Contributions: R.P. conceived the study, aided in sample collection, analyzed the data; M.S. aided in sample collection and manuscript writing; D.D. supported analysis and manuscript writing; J.M. processed samples and crossdated tree-rings and fire scars; J.S. located study sites, aided in sample collection and provided management information; J.L. located study sites, provided forest information, and contributed to manuscript writing and review.

Conflicts of Interest: The authors declare no conflict of interest.

\section{References}

1. Swetnam, T.W.; Allen, C.D.; Betancourt, J.L. Applied historical ecology: Using the past to manage for the future. Ecol. Appl. 1999, 9, 1189-1206. [CrossRef]

2. Schulte, L.A.; Mladenoff, D.J. Severe wind and fire regimes in northern Wisconsin (USA) forests: Historical variability at the regional scale. Ecology 2005, 86, 431-445. [CrossRef]

3. Schulte, L.A.; Mladenoff, D.J.; Burrows, S.N.; Sickley, T.A.; Nordheim, E.V. Spatial controls of Pre-EuroAmerican wind and fire in Wisconsin (USA) forests: A multiscale assessment. Ecosystems 2005, 8, 73-94. [CrossRef]

4. McMurry, E.R.; Stambaugh, M.C.; Guyette, R.P.; Dey, D.C. Fire scars reveal the source of New England's 1780 Dark Day. Int. J. Wildland Fire 2007, 16, 266-270. [CrossRef]

5. Dey, D.C.; Guyette, R.P. Anthropogenic fire history and red oak forests in south-central Ontario. For. Chron. 2000, 76, 339-347. [CrossRef]

6. Curtis, J.T. The Vegetation of Wisconsin; University of Wisconsin Press: Madison, WV, USA, 1959.

7. Rohe, R.; Miller, S.; Eisele, T. One Hundred Years of Wisconsin Forestry; Trails Custom Publishing: Black Earth, WI, USA, 2004.

8. Stewart, O.C. Barriers to understanding the influence of use of fires by aborigines on vegetation. Proc. Second Annu. Tall Timbers Fire Ecol. Conf. 1963, 2, 117-126.

9. Wisconsin Historical Society. Available online: http://www.wisconsinhistory.org/ (accessed on 18 August 2016).

10. Guyette, R.P.; Muzika, R.M.; Dey, D.C. Dynamics of an anthropogenic fire regime. Ecosystems 2002, 5, 472-486.

11. Guyette, R.P.; Spetich, M.A.; Stambaugh, M.C. Historic fire regime dynamics and forcing factors in the Boston Mountains, Arkansas, USA. For. Ecol. Manag. 2006, 234, 293-304. [CrossRef]

12. Stambaugh, M.C.; Guyette, R.P.; Marschall, J.M. Fire history in the Cherokee Nation of Oklahoma. Human Ecol. 2013, 41, 749-758. [CrossRef]

13. Torretti, R.L. Traditional Stories from Non-Traditional Stories: Tree-Rings Reveal Historical Use of Fire by Native Americans on Lake Superior's Southern Shore. Master's Thesis, Northern Michigan University, Marquette, MI, USA, 2003.

14. Loope, W.L.; Anderton, J.B. Human versus lightning ignition of presettlement surface fires in coastal pine forests of the upper Great Lakes. Am. Midland Nat. 1998, 140, 206-218. [CrossRef]

15. Mooney, J. The Aboriginal population of America north of Mexico. In Smithsonian Miscellaneous Collections; Swanton, J., Ed.; Smithsonian Institution: Washington, DC, USA, 1928; Volume 80, pp. 1-40.

16. Swanton, J.R. Bureau of American Ethnology; The Indian tribes of North America Smithsonian Institution: Washington, DC, USA, 1952.

17. Terrell, J.U. American Indian Almanac; The World Publishing Co.: New York, NY, USA, 1971; p. 494. 
18. Sands, B.A.; Abrams, M.D. A 183-year history of fire and recent fire suppression impacts in select pine and oak forest stands of the Menominee Indian Reservation, Wisconsin. Am. Midland Nat. 2011, 166, 325-338. [CrossRef]

19. Nowacki, G.L.; Abrams, M.D.; Lorimer, C.G. Composition, structure, and historical development of northern red oak stands along an edaphic gradient in north-central Wisconsin. For. Sci. 1990, 36, $276-292$.

20. Ecological Landscapes of Wisconsin. State of Wisconsin. Available online: http://dnr.wi.gov/topic/ landscapes/book.html (accessed on 26 August 2016).

21. Peel, M.C.; Finlayson, B.L.; McMahon, T.A. Updated world map of Koppen-Geiger climate classification. Hydrol. Earth Syst. Sci. 2007, 11, 1633-1644. [CrossRef]

22. Kotar, J.; Kovach, J.A.; Locey, C.T. Field Guide to Forest Habitats Types of Northern Wisconsin; Wisconsin Department of Natural Resources: Madison, WI, USA, 1998.

23. Harris, R.C.; Matthews, G.J. Historical Atlas of Canada; University of Toronto Press: Toronto, ON, 1987; Volume 1.

24. Stokes, M.A.; Smiley, T.L. An Introduction to Tree-Ring Dating; University of Arizona Press: Tucson, AZ, USA, 1996; p. 73.

25. Holmes, R.L.; Adams, R.; Fritts, H.C. Quality Control of Crossdating and Measuring: A User's Manual for Program COFECHA. In Tree-Ring Chronologies of Western North America: California, Eastern Oregon and Northern Great Basin; University of Arizona, Laboratory of Tree-Ring Research: Tucson, AZ, USA, 1986; pp. 41-49.

26. Grissino-Mayer, H.D.; Holmes, R.L.; Fritts, H.C. International Tree-Ring Data Bank Program Library Version 2.0 User's Manual; University of Arizona, Laboratory of Tree-Ring Research: Tucson, AZ, USA, 1996; p. 106.

27. Cook, E.R.; Meko, D.M.; Stahle, D.W.; Cleaveland, M.K. North American Summer PDSI Reconstructions; NOAA/NGDC, Paleoclimatology Program: Boulder, CO, USA, 2004.

28. Muzika, R.M.; Guyette, R.P.; Stambaugh, M.C.; Marschall, J.M. Fire, drought, and humans in a heterogeneous Lake Superior landscape. J. Sustain. For. 2015, 34, 49-70. [CrossRef]

29. Guyette, R.P.; Stambaugh, M.C. A quantitative method for estimating long-term influence of human ignitions on fire regimes. In Uniting Research, Education, and Management, Proceedings of 5th International Fire Ecology and Management Congress, Portland, OR, USA, 3-7 December 2012.

30. Dietrich, J.H. The Composite Fire Interval - A Tool for more Accurate Interpretation of Fire History; USDA Forest Service General Technical Report RM-81; Rocky Mountain Forest and Range Experiment Station Forest Service US, Department of Agriculture: Tucson, AZ, USA, 1980; pp. 8-14.

31. SAS/STAT. SAS User's Guide: Statistics, 5th ed.; SAS Institute: Cary, NC, USA, 2002; p. 955.

32. Cwynar, L.C. The recent fire history of Barron Township, Algonquin Park. Can. J. Bot. 1977, 55, $1524-1538$. [CrossRef]

33. Guyette, R.P.; Stambaugh, M.C.; Dey, D.C.; Muzika, R.M. Estimating fire frequency with the chemistry of climate. Ecosystems 2012, 15, 322-335. [CrossRef]

34. Schlesier, K.H. Epidemics and Indian Middlemen: Rethinking the Wars of the Iroquois, 1609-1653. Ethnohistory 1976, 23, 129-145. [CrossRef] [PubMed]

35. Blair, E.H. The Indian tribes of the Upper Mississippi and Great Lakes Region; University of Nebraska Press: Lincoln, MT, USA, 1911.

36. Kay, J. The fur trade and Native American population growth. Ethnohistory 1984, 31, 265-287. [CrossRef]

37. Fenn, E.A. PoxAmerica: The Great Smallpox Epidemic of 1775-82; Cahners Business Information, Inc.: New York, NY, USA, 2001.

38. Seventy-two years' recollections of Wisconsin. Available online: http://www.wisconsinhistory.org/ turningpoints/search.asp?id=28 (accessed on 26 August 2016).

39. Schoolcraft, H.R. Narrative of an expedition through the upper Mississippi to Itasca Lake, 1832; Harper \& Brothers: New York, NY, USA, 1834.

40. Heinselman, M.L. Fire in the virgin forests of the Boundary Waters Canoe Area, Minnesota. Quat. Res. 1973, 3, 329-382. [CrossRef]

41. Guyette, R.P.; Palik, B.; Dey, D.C. Three Centuries of Burning on the Chippewa National Forest and the Leech Lake Band of Ojibwa's near Cass Lake, Minnesota. Unpublished work. 2015.

42. Guyette, R.P.; Dey, D.C. A Pre-Settlement Fire History of an Oak-Pine Forest near Basin Lake, Algonquin Park, Ontario; Forest Research Report No. 132; Ontario Forest Research Institute: Marie, Canada, 1995. 
43. Guyette, R.P.; Dey, D.C. A Dendrochronological Fire History of Opeongo Lookout in Algonquin Park, Ontario; Forest Research Report No. 134; Ontario Forest Research Institute: Ontario, Canada, 1995.

44. McEwan, R.; Aldrich, S.; Bauer, J.; Gentry, C.; Kernan, J.; Lusteck, R.; Martinez, P.; Shapiro, L.; Sprenger, C.; Vining, M.; et al. A tree-ring based fire history reconstruction of red pine (Pinus resinosa) forests, Lake Itasca, Minnesota. Ohio Academy of Science 114th Annual Meeting Abstracts. Ohio J. Sci. 2005, 105, A-36.

45. Drobyshev, I.; Goebel, P.C.; Hix, D.M.; Corace, R.G., III; Semko-Duncan, M.E. Pre- and post-European settlement fire history of red pine dominated forest ecosystems of Seney National Wildlife Refuge, Upper Michigan. Can. J. For. Res. 2008, 38, 2497-2514. [CrossRef]

46. Use of acorns for food in California: past, present and future. Available online: http://timeless-environments. blogspot.com/p/use-of-acorns-for-food-in-california.html (accessed on 18 August 2016).

47. Kautz, E.W. Prescribed fire in blueberry management. Fire Manag. Notes 1987, USDA FS 48, 9-12.

48. Parkman, F. The Jesuits in North America in the Seventeenth Century; Little, Brown and Company: Boston, MA, USA, 1983.

49. Baskin, Y. The Work of Nature: How The Diversity Of Life Sustains Us; Island Press: Washington, DC, USA, 1997.

50. Hood, G.A.; Bayley, S.E.; Olson, W. Effects of prescribed fire on habitat of beaver (Castor canadensis) in Elk Island National Park, Canada. For. Ecol. Manage. 2007, 239, 200-209. [CrossRef]

51. Schulte, L.A.; Mladenoff, D.J.; Crow, T.R.; Merrick, L.; Cleland, D.T. Homogenization of northern USA Great Lakes forests as a result of land use. Landsc. Ecol. 2007, 22, 1089-1103. [CrossRef]

52. Matile, R. Those Marvelous Ojibwa Built Birch Bark Canoes; The Canadian Canoe Museum: Oswego, IL, USA, 2013.

53. Swenson, J.C. Canoe Passages: Cross-Cultural Conveyance in USA and Canadian Literature. Ph.D. Thesis, University of Iowa, Iowa City, IA, USA, 2007.

54. Burns, R.M.; Honkala, B.H. Silvics of North America: Volume 2. Hardwoods; USDA Forest Service: Washington, DC, USA, 1990; pp. 158-171.

55. Fowells, H.A. Silvics of Forest Trees of the United States/Prepared by the Division of Timber Management Research, Forest Service, 1965; Agricultural Handbook USDA no. 271; USDA Forest Service: Washington, DC, USA, 1965.

56. Pyne, S.J. Fire in America; University of Washington Press: Princeton, NJ, USA, 1982; p. 655.

57. Kellogg, L.P. Early Narratives of the Northwest, 1917, 1634-1699; Charles Scribner's Sons: New York, NY, USA, 1917.

58. Houghton, D. Vaccination of the Indians. In Henry Schoolcraft, Summary Narrative of an Exploratory Expedition to the Sources of the Mississippi River; Philadelphia, Lippincott, Grambo, and Co.: Philadelphia, PA, USA, 1855; pp. 574-581.

59. Fenn, E.A. PoxAmerica: The Great Smallpox Epidemic of 1775-82; Hill \& Wang: New York, NY, USA, 2001.

60. Schulte, L.A.; Mladenoff, D.J. The original USA Public Land Survey Records: Their use and limitations in reconstructing presettlement vegetation. J. For. 2001, 99, 5-10.

61. Simard, A.J.; Haines, D.A.; Blank, R.W.; Frost, J.S. The Mack Lake Fire; USDA Forest Service: St, Paul, MN, USA, 1983.

(C) 2016 by the authors; licensee MDPI, Basel, Switzerland. This article is an open access article distributed under the terms and conditions of the Creative Commons Attribution (CC-BY) license (http://creativecommons.org/licenses/by/4.0/). 